\title{
How Good Politics Results in Bad Policy: The Case of Biofuel Mandates
}

\section{Citation}

Lawrence, Robert Z. 2010. How Good Politics Results in Bad Policy: The Case of Biofuel Mandates. HKS Faculty Research Working Paper Series RWP10-044, John F. Kennedy School of Government, Harvard University

\section{Published Version}

http://web.hks.harvard.edu/publications/workingpapers/citation.aspx?Publd=7478

\section{Permanent link}

http://nrs.harvard.edu/urn-3:HUL.InstRepos:4553312

\section{Terms of Use}

This article was downloaded from Harvard University's DASH repository, and is made available under the terms and conditions applicable to Other Posted Material, as set forth at http:// nrs.harvard.edu/urn-3:HUL.InstRepos:dash.current.terms-of-use\#LAA

\section{Share Your Story}

The Harvard community has made this article openly available.

Please share how this access benefits you. Submit a story.

Accessibility 


\section{How Good Politics Results in Bad Policy: The Case of Biofuel Mandates \\ Faculty Research Working Paper Series}

\section{Robert Z. Lawrence}

Harvard Kennedy School

\section{November 2010 RWP10-044}

The views expressed in the HKS Faculty Research Working Paper Series are those of the author(s) and do not necessarily reflect those of the John F. Kennedy School of Government or of Harvard University. Faculty Research Working Papers have not undergone formal review and approval. Such papers are included in this series to elicit feedback and to encourage debate on important public policy challenges. Copyright belongs to the author(s). Papers may be downloaded for personal use only. 


\title{
How Good Politics Results in Bad Policy: The Case of Biofuel Mandates ${ }^{1}$
}

\author{
Robert Z. Lawrence ${ }^{2}$
}

CID Working Paper 200

and

Belfer Center Discussion Paper 2010-10

September 2010

(C) Copyright 2010 Robert Z. Lawrence and the President and

Fellows of Harvard College
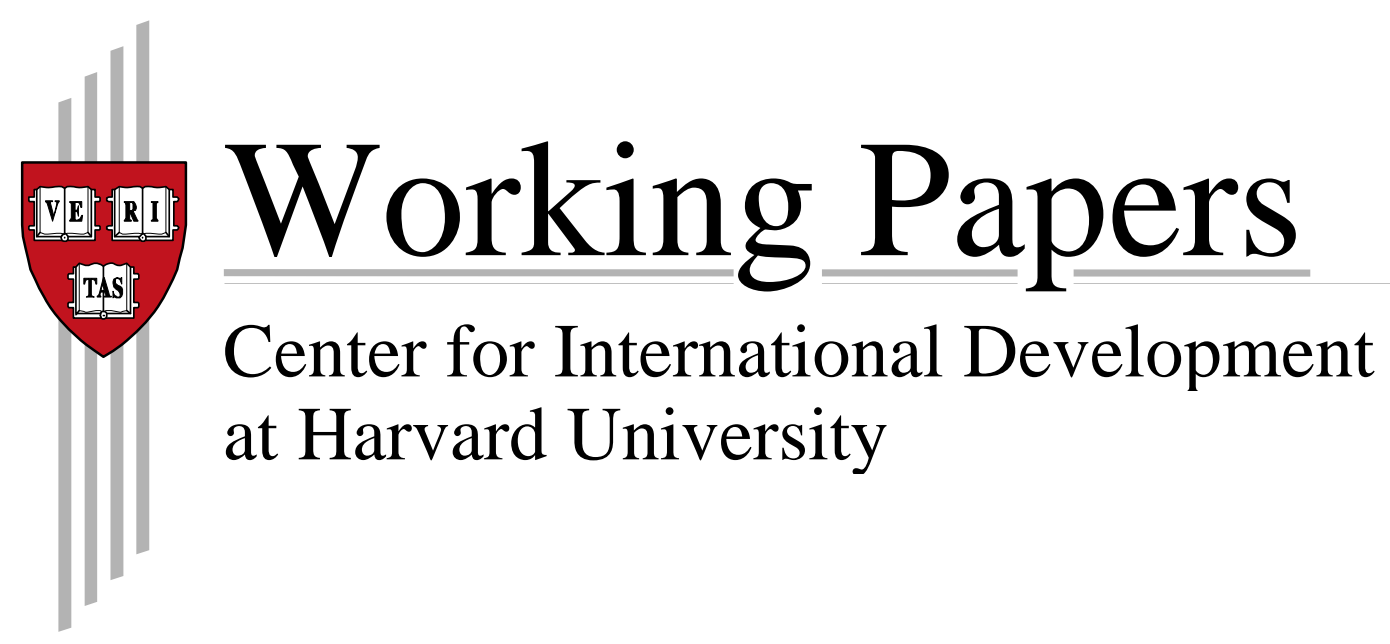

\footnotetext{
${ }^{1}$ This paper draws very heavily on research undertaken by Charan Devereaux. I am indebted also to Tom Beckford for his extensive research assistance and for funding to the Global Energy Partnership Grant to the Environment and Natural Resources Program within the Belfer Center for Science and International Affairs at Harvard Kennedy School. I also thank Henry Lee for his helpful comments.

${ }^{2}$ Robert Z. Lawrence is the Albert L. Williams Professor of International Trade and Investment at Harvard Kennedy School, a Senior Fellow at the Peterson Institute for International Economics, and a Research Associate at the National Bureau of Economic Research.
} 


\title{
How Good Politics Results in Bad Policy: The Case of Biofuel Mandates
}

\author{
Robert Z. Lawrence
}

\begin{abstract}
Biofuels have become big policy and big business. Government targets, mandates, and blending quotas have created a growing demand for biofuels. Some say that the U.S. biofuels industry was created by government policies. But recently, biofuels have become increasingly controversial. In this paper Lawrence argues that the growing list of concerns about the impact of biofuel targets and mandates - are the predictable result of a failure to follow the basic principles of good policy-making. Good policy-making requires developing a policy goal or target (i.e., reducing greenhouse gas emissions, reducing oil consumption, or increasing rural economic development) and designing an instrument to efficiently meet that particular goal. The more precise the goal, the better. In addition, for each target, there should be at least one policy instrument. You cannot meet two goals with only one instrument. Lawrence argues that the current U.S. biofuels mandates do not represent the most efficient or precise instrument to meet any of the policy's stated goals.

While this paper argues against mandates, it should not be understood as an attack on all biofuels policies. Three are especially worthy of consideration. First, there are good reasons for the government to subsidize research on different alternative sources of energy such as biofuels. Second, there may be a role for government coordination and investment in biofuels infrastructure which are essentially public goods that private actors cannot undertake on their own. And third, there are also good reasons for removing the tariffs that are imposed by both the European Union and the United States on imported ethanol and biodiesel. These trade barriers not only reduce any potential environmental benefits that could be achieved from using these products, but also limit the development benefits than poor countries might enjoy from producing them.
\end{abstract}

Keywords: biofuels, sustainable development, environmental policy, sustainability, market design, bio-energy, ethanol, sugarcane

JEL subject codes: Q01, Q56, Q4, Q48, L52, F14, F18 


\section{Citation, Context, and Program Acknowledgements}

This paper may be cited as:

Lawrence, Robert Z. "How Good Politics Results in Bad Policy: The Case of Biofuel Mandates.” Discussion Paper 2010-10, Belfer Center for Science and International Affairs; CID Working Paper No. 200, Center for International Development, Cambridge, Mass: Harvard University. September 2010.

Comments are welcome and may be directed to Robert Lawrence at the John F. Kennedy School of Government, Harvard University, 79 JFK Street, Cambridge, MA 02138, robert_lawrence@harvard.edu. This paper is available at http://www.hks.harvard.edu/centers/cid/publications/faculty-working-papers.

Robert Z. Lawrence is the Albert L. Williams Professor of International Trade and Investment at Harvard Kennedy School, a Senior Fellow at the Peterson Institute for International Economics, and a Research Associate at the National Bureau of Economic Research.

The Sustainability Science Program at Harvard's Center for International Development harnesses the University's strengths to promote the design of institutions, policies, and practices that support sustainable development. The Program addresses the challenge of sustainable development by: advancing scientific understanding of human-environment systems; improving linkages between research and policy communities; and building capacity for linking knowledge with action to promote sustainability. The Program supports major initiatives in policy-relevant research, faculty research, training of students and fellows, teaching, and outreach communities on the one hand, and relevant policy and management communities on the other. See

http://www.cid.harvard.edu/sustsci.

The Environment and Natural Resources Program at the Belfer Center for Science and International Affairs is the center of the Harvard Kennedy School's research and outreach on public policy that affects global environment quality and natural resource management. Its mandate is to conduct policy-relevant research at the regional, national, international, and global level, and through its outreach initiatives to make its products available to decision-makers, scholars, and interested citizens. More information can be found on ENRP's web site at www.belfercenter.org/enrp or from director Henry Lee (henry_lee@harvard.edu) or program administrator Amanda Swanson (amanda_swanson@harvard.edu) at ENRP, Harvard Kennedy School, 79 JFK Street, Cambridge, MA 02138 USA.

\section{DISCLAIMER}

The views expressed within this paper are the authors' and do not necessarily reflect those of the organizations they are affiliated with, its members, nor any employee or persons acting on behalf of any of them. In addition, none of these make any warranty, expressed or implied, assumes any liability or responsibility for the accuracy, completeness or usefulness of any information, apparatus, product or process disclosed or represents that its use would not infringe privately owned rights, including any party's intellectual property rights. References herein to any commercial product, process, service or trade name, trade mark or manufacturer does not necessarily constitute or imply any endorsement, or recommendation or any favoring of such products. The CID Working Papers have not undergone formal review and approval. Such papers are included in this series to elicit feedback and to encourage debate on important public policy challenges. Copyright belongs to the author. Papers may be downloaded for personal use only. 


\section{TABLE OF CONTENTS}

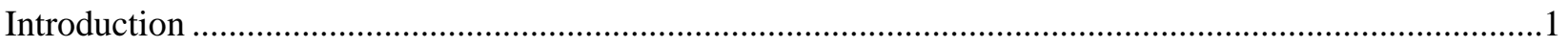

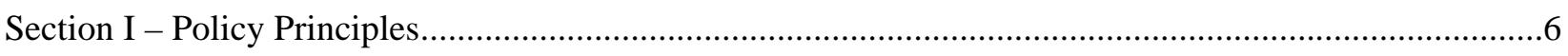

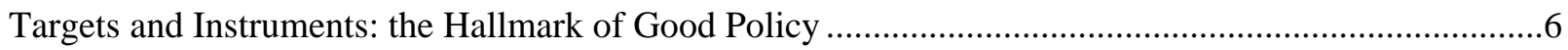

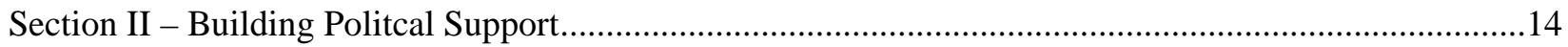

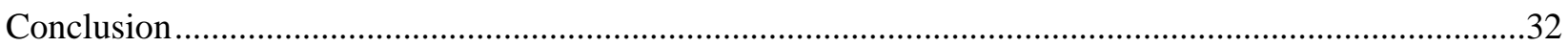




\section{Introduction}

Biofuels have become big policy and big business. The United States, Europe, and Brazil require blending biofuel-liquid fuel derived from plant material—in transportation fuel. Often, production is subsidized and tariffs restrict trade from other countries. Additional government support includes loan guarantees for biofuel plant construction, subsidies to farmers who grow biofuel feedstocks, and funding for biofuel research and development.

Government targets, mandates, and blending quotas have created a growing demand for biofuels. Some say that the U.S. biofuels industry was created by government policies. Between 2000 and 2007, global production of ethanol for transport fuel tripled, from 17 billion liters to more than 52 billion liters. Investment in biofuels production capacity probably exceeded \$4 billion worldwide in 2007. Recent figures show continuing growth in biofuel use. Between 2007 and 2008, the percentage of ethanol in global gasoline use increased from 3.78 percent to 5.46 percent. $^{3}$

Biofuels have been promoted to deal with a number of problems. Some biofuel supporters argue that the fuel represents an ideal combination of benefits, saying production and use of biofuels improves the environment by reducing greenhouse gas emissions (GHG), contributes to rural prosperity, helps farmers, creates development opportunities in poorer countries, improves engine performance, offers a renewable alternative to oil and other fossil fuels, and provides energy security as a domestically-produced fuel. In the United States, for example, George W. Bush supported biofuels during his presidency, particularly corn ethanol, and the United States became the largest ethanol producer in the world. ${ }^{4}$ As Bush put it,

Ethanol is good for our rural communities. It's good economic development for rural America. You know, new bio-refinery construction creates jobs and local tax revenues. When the family farmer's doing well, it's good for the local merchants. Ethanol is good for the environment. I keep emphasizing that we can be good stewards of our environment and at the same time continue with our

\footnotetext{
3 Biofuels provide 1.8 percent of the world's transport fuel. All statistics in this paragraph from United Nations Environment Programme, International Panel for Sustainable Resource Management, Towards Sustainable Production and Use of Resources: Assessing Biofuels, October 2009, p. 15

4 Renewable Fuel Association (RFA), http://www.ethanolrfa.org/industry/statistics/
} 
economic expansion. And ethanol will help meet that strategy. You don't have to choose between good environment and good economics. You can have both by the use of technology. And ethanol is an example of what I'm talking about. And ethanol's good for drivers. Ethanol is home-grown. Ethanol will replace gasoline consumption. It's a good—ethanol is good for the whole country. ${ }^{5}$

Different countries have emphasized different reasons for supporting biofuels. In the United States, though leaders tout a variety of benefits, the primary reasons for supporting biofuels have been supporting farmers, increasing energy security (reducing U.S. dependence on foreign oil) and improving the environment. The United States has required the use of 36 billion gallons of biofuel in the nation's transportation fuels supply by 2022. In Europe, where biofuel production is primarily biodiesel from rapeseed, environmental legislation has mandated that biofuels make up 10 percent of transport fuel by 2020. In Brazil, where ethanol is produced from sugar cane, biofuels represent a way to increase economic independence by reducing the need for foreign oil and supporting the country's sugar cane production. With many flexible-fuel cars that can run on gasoline, ethanol, or a mixture of both, Brazil's drivers often find that ethanol is a cheaper choice at the pump.

But recently, biofuels have become increasingly controversial. Some environmentalists challenge the assertion that biofuels, particularly corn ethanol, offer a meaningful reduction in greenhouse gas emissions. Environmentalists are also concerned that biofuel feedstock production threatens water supplies and undeveloped land, such as forests and wetlands. Many have also argued that expanding production of biofuels puts pressure on available agricultural land, increasing food prices and seriously impacting poor consumers. As a result of these concerns, some say that biofuels represent a diversion from creating the tough polices necessary to mitigate climate change, increase rural prosperity, and increase energy security. Some criticize using government money to support biofuel programs, especially corn ethanol, arguing that public resources are being wasted on an ineffective program. "The corn-based ethanol program is going to be considered one of the biggest follies ever implemented in energy policy anywhere in

5 George W. Bush, 2006. http://georgewbush-whitehouse.archives.gov/news/releases/2006/04/20060425.html 
the world in the history of energy policy,” says Amy Myers Jaffe of Rice University’s James A. Baker III Institute. "Ethanol is not a solution to greenhouse gases.”6

In addition, there is inconsistency between what biofuel supporters say and what they really want from government policies. Government policies reflect these muddled priorities. For example, though European biofuel targets are said to be implemented solely to reduce green house gas emissions, tariffs on imported biofuels remain in place, benefitting local farmers as part of European agricultural policy.

In this paper I will argue that these unfortunate outcomes-namely, the growing list of concerns about the impact of biofuel targets and mandates - are the predictable result of a failure to follow the basic principles of good policy-making. Good policy-making requires developing a policy goal or target (i.e., reducing greenhouse gas emissions, reducing oil consumption, or increasing rural economic development) and designing an instrument to efficiently meet that particular goal. The more precise the goal, the better. In addition, for each target, there should be at least one policy instrument. You cannot meet two goals with only one instrument. I will argue that the current U.S. biofuels mandates do not represent the most efficient or precise instrument to meet any of the policy's stated goals.

Although current biofuel mandates are not good policy, they certainly represent an issue that has achieved political success. In the United States, both Republicans and Democrats support biofuels, especially in farm states. “There is zero daylight” between Democrats and Republicans in the region, says Ken Cook, president of Environmental Working Group, a nonprofit research policy group in Washington. "All incumbents and challengers in Midwestern farm country are by definition ethanolics." ${ }^{7}$ In the United States, ethanol is also an important issue for presidential candidates. The first state in both the Republican and Democrat presidential primary elections is Iowa, which grows corn for the ethanol industry. "You can’t trash ethanol and expect to win in Iowa,” says Iowa State University political science professor Steffen Schmidt. ${ }^{8}$ Strong political

6 Amy Myers Jaffe, Baker Institute, Rice University quoted in Heat, a Frontline documentary film, PBS, October, 2008. http://www.pbs.org/wgbh/pages/frontline/heat/etc/script.html

7 Alexei Barrionuevo, "The Energy Challenge: A Modern Gold Rush; For Good or Ill, Boom in Ethanol Reshapes Economy of Heartland,” The New York Times, June 25, 2006.

8 Shailagh Murray, “Ethanol Undergoes Evolution as Political Issue,” The Washington Post, March 13, 2007, Pg. A06. ${ }^{9} \quad$ In fact of course, microeconomic theory suggests that the actual incidence of taxes do not fall fully on those who write the checks. For example, a sales tax may not only raise the cost to buyers but also reduce the price received by sellers. 
support has maintained key subsidies and polices for ethanol for 30 years, and those forces will remain.

A great source of political strength is that biofuels can be justified in so many ways, which has been tremendously useful in building support for biofuels. Many groups have become interested in biofuels because production and use of these fuels impacts three major policy areas-energy policy, environmental policy, and agricultural policy.

Since the development of the automobile, biofuel supporters have emphasized a variety of benefits of producing and using the fuel. Reviewing the history of biofuels, we can observe the changing rationales for biofuel use over time. Back in 1907, Congress passed legislation meant to spur the development of a domestic transportation biofuels industry in hopes of creating competition for Standard Oil. In the 1930s, biofuel was touted as a strategy for dealing with agricultural surpluses and low commodity prices. When oil prices were high in the late 1970s, ethanol was seen as a gasoline extender. During the 1990s, ethanol was seen as an aide to combating urban smog in large U.S. cities. As concerns about greenhouse gases intensified in the 2000's, Europe adopted biofuels as a way to reduce emissions. While the United States was concerned about emissions as well, a biofuels mandate was also adopted for national security reasons, namely, concerns about oil imports, and to support Midwestern corn farmers.

The variety of rationales for promoting biofuels has been useful in gaining support. A lack of precision or clarity about policy goals, sometimes known as constructive or strategic ambiguity, can be very useful when advancing a political purpose. The ambiguity surrounding the question of why government should support transportation biofuels_or what a mandate would specifically accomplish—helped create the necessary support to facilitate the passage of the 2005 Renewable Fuels Standards and the 2007 revised standard (RFS2). An RFS could be all things to all people. Farm groups, industry groups, unions, some environmental groups, certain political groups (such as national security groups who wanted to reduce dependence on Middle East oil), consumer groups, evangelicals, and a number of car-makers backed a government biofuel mandate-most for different reasons. But ambiguity can generate subsequent controversy. For example, while some groups initially supported a Renewable Fuels Standard for environmental reasons, concerns grew about how to ensure that the RFS would indeed reduce carbon emissions as hoped. 
Biofuels supporters also gained a political advantage by pursuing the idea of a mandate. One advantage of a mandate is that it hides the true costs of a given policy. The cost of mandate is less clear than a more targeted instrument, such as a tax. The problem with taxes (from a political viewpoint) is that their cost is transparent. It is clear who will pay the cost of the tax, and how much will be paid. ${ }^{9}$ A great political benefit of a mandate is that no one knows exactly what it will cost or who will pay. Therefore, while it may be clear who "wins" as a result of the mandate, it is less clear who "loses."

Furthermore, in the 2005 and 2007 campaigns for a Renewable Fuels Standard, an RFS was sometimes perceived as a more acceptable or easy way to meet environmental or energyrelated goals than more controversial policies such as implementing a carbon tax. In this way, the US Renewable Fuels Standard represents a "second-best option,” an option that supporters may not see as the optimal policy, but is said to represent some progress on issues of concern. For example, some environmental groups saw a biofuels mandate as a realistic option when compared to increasing fuel economy standards - a policy that had been strongly opposed by car makers and the United Auto Workers union for many years.

It is also important to consider that the 2005 Renewable Fuels Standard and the 2007 revised standard were not passed alone, but as part of larger energy bill packages. Combining different legislative issues into packages creates the potential for trade-offs. These trade-offs can neutralize opposition to any given policy and create a broader coalition. For example, in initial negotiations, a biofuels mandate was combined with legislation that was favorable to the oil industry, a move that helped gain some support for a biofuels mandate (or at least reduced resistance).

While the resulting breadth of support for biofuels has been tremendously useful for building political support for biofuel use, it is detrimental to good policy. Biofuel mandates are good politics, but not good policy - an example where good policy and politics work against each other. As long as groups do not need to agree on why we need to mandate biofuels, then there is support for their use. If we required policymakers to justify how biofuels represent the most efficient solution to any one particular policy goal, it would become apparent that biofuels are not the most efficient solution to any particular market failure.

Clearly, there is a dilemma. The principles of good policymaking require precision and clarity of purpose, but the political realities of forming coalitions often benefit from ambiguity, 
hiding costs, accepting second-best justifications, and packaging policies together to further broaden support. These dynamics can create policies which are unlikely to achieve their stated goals, as has been the case of biofuels.

This paper is a plea for avoiding such obfuscation. A technology (such as biofuels) is not a policy or an end in itself, but an instrument. First we should be agreeing on goals. Only then can we decide if a particularly technology is the most efficient way to meet the policy goal. Focusing on the desired goal or target will increase the chances that policies will be rational and efficient.

While this paper argues against mandates, it should not be understood as an attack on all biofuels policies. Three are especially worthy of consideration. First, there are good reasons for the government to subsidize research on different alternative sources of energy such as biofuels. Indeed, precisely because biofuels could help in increasing energy independence, or in providing transportation fuels that reduce $\mathrm{CO} 2$ emissions, breakthroughs in knowledge about such technologies are likely to provide social benefits far in excess of the private rewards to innovators. But this calls for precisely targeted alternative energy R\&D programs and subsidies with explicit objectives rather than policies that encourage the widespread use of particular technologies with ill-defined purposes.

Second, there may be a role for government coordination and investment in biofuels infrastructure which are essentially public goods that private actors cannot undertake on their own. And third, there are also good reasons for removing the tariffs that are imposed by both the European Union and the United States on imported ethanol and biodiesel. These trade barriers not only reduce any potential environmental benefits that could be achieved from using these products, but also limit the development benefits than poor countries might enjoy from producing them.

\section{Section I - Policy Principles}

\section{Targets and Instruments: the Hallmark of Good Policy}

Many economists would agree that most decisions are best left to be determined by market forces. However, there are times when private actors make decisions that fail to fully incorporate the social consequences of their actions. In the face of such failures, government policy may be warranted. The classic example is pollution. If private firms are not required to 
take account of pollution associated with their production, they will produce more than is socially optimal-there will be "market failure." In this case, policy intervention can achieve a better outcome than the free market-for example through a pollution tax.

Economists have devoted a lot of time to thinking about the relationship between policy goals and the policy instruments needed to achieve these goals. Their work has come up with two important lessons for efficient government intervention to correct market failures. First, "if you want to hit the bulls-eye, use an arrow not a pitchfork." Policy instruments should be chosen so that they achieve their objectives in the most precise way possible. Second, successful policy requires at least as many different instruments as it has targets or objectives. ${ }^{10}$ Unless two targets happen to be perfectly aligned, both targets cannot be achieved with a single instrument-you cannot hit two bull's-eyes with just one arrow. ${ }^{11}$

While these principles may be obvious in theory, in practice, they are often violated. In order to determine if biofuels policies meet the criteria described above, we must first consider the policy goals that biofuel targets, subsidies, and mandates are said to address. Then we should ask: does biofuel policy represent the most efficient way to meet these goals? Are the correct instruments being used and are their enough of them?

Most commonly, three policy goals are cited to support government promotion of biofuels: First, reducing economic vulnerability due to dependence on foreign oil; second, combating climate change by reducing carbon dioxide emissions; and third, providing farmers and rural areas much-needed income. Applying our principles, we immediately see that simply promoting biofuels production through a mandate is highly unlikely to achieve all of these goals simultaneously. It is just one instrument and there are three goals. Moreover, it is also unlikely to achieve any of them efficiently. An efficient solution to reducing GHG emissions, for example, would require equating all possible abatement measures to have similar marginal costs. But there is no reason to believe that the marginal cost of the additional ethanol use required to meet a specific mandate chosen years in advance would be less than the many other ways emissions could be reduced.

If these are the three goals (energy security, carbon emissions, and rural development) that should be met, at least three separate price instruments are required. For example, one

\footnotetext{
10 Jan Tinbergen, Economic Policy: Principles and Design, Chicago: Rand McNally \& Co, 1967.
}

11 W. Max Corden, Trade Policy and Economic Welfare, $2^{\text {nd }}$ edition, Oxford: Clarendon Press, 1997 
combination of instruments would be to use an oil import tariff as the instrument for reducing dependence on foreign oil, a carbon tax to combat climate change, and subsidies to poor farmers and rural areas. In what follows, I elaborate on the logic of this approach. It involves two steps. First identifying the nature of the market failure, and second considering the efficient way to compensate for it.

\section{Target: Energy Security}

If left to the market, the United States would continue to meet most of its needs for fuel by importing oil because domestic production of petroleum and its substitutes is more costly. Generally, one would say, this is the most efficient way to obtain such fuels. However, dependence on foreign oil has additional social costs that are not automatically reflected in the price. Some of these costs are economic. First, oil price shocks have major implications for the macroeconomy. By suddenly withdrawing purchasing power, higher oil prices can induce recessions. By boosting the price level, they can create inflationary pressures and problems for monetary policy. Other costs are political. Oil supply disruptions could be triggered by foreign suppliers using oil to their strategic advantage. Indeed, U.S. political and military involvement in the Middle East indicates the strategic importance of oil and the U.S. dependence on imports.

\section{Instrument: Tariff on Imported Oil, Increased Fuel Efficiency}

If the problem is dependence on foreign oil, the solution is to discourage consumption of foreign oil and encourage domestic production of substitutes. The appropriate price instrument would be an import tariff which will raise domestic prices of oil and oil substitutes, thereby discouraging consumption and encouraging domestic production of oil and oil substitutes.

\section{Target: Reduce Carbon Emissions}

When oil is burned, carbon and other greenhouse gases (GHG) are released into the atmosphere, leading to global warming. ${ }^{12}$ Although the effects will vary across different regions of the world and the final impact is uncertain, significant environmental damages are expected.

12 IPCC Fourth Assessment Report: Climate Change 2007 (AR4), http://www.ipcc.ch/pdf/assessmentreport/ar4/syr/ar4_syr.pdf 
Carbon dioxide and other GHGs are released through activities such as power production, agriculture, industrial activity, and transportation. Nearly 40 percent of carbon dioxide emissions in the United States come from vehicles. However, transportation only makes up about 13 percent of emissions worldwide. ${ }^{13}$ But if car ownership grows significantly in developing countries such as China, India and Brazil, emissions from transportation will increase.

In the campaigns that created the biofuel mandates and targets in the United States and Europe, proponents emphasized the environmental benefits that could come from biofuels use through reduced GHG emissions. As EU Commissioner for Trade Peter Mandelson put it, "biofuel policy is not ultimately an industrial policy or an agricultural policy -it is an environmental policy, driven above all by the greenest outcomes."14 In the United States, the 2007 revised Renewable Fuels Standard (also known as RFS-2) requires ethanol production and use to emit 20 percent less greenhouse gases than gasoline, and advanced biofuels (made from agricultural waste or crops like switch grass) to release 50 percent less. The EU's Renewable Energy Directive would require 10 percent of all transport fuels to come from renewable sources by 2020 and to count as a renewable fuel, biofuels must contribute at least 35 percent less carbon emissions than fossil fuels. (It is clear that other motivations exist for biofuel policy. Though biofuel targets are part of the EU's environmental policy, tariffs on biofuel feedstocks remain in place.)

However, the effectiveness of biofuels in reducing emissions has been called into question. Certainly, the net emissions of biofuels vary significantly depending on the feedstocks and technologies used in their production and consumption. In addition, there is concern that the large-scale diversion of agricultural resources to fuel could threaten protected areas such as rainforests, turning it into farmland.

\section{Instrument: Pigouvian Tax or Cap and Trade}

To target carbon dioxide emissions, the most efficient policy choice would be to implement a pigouvian tax or a cap and trade program to raise the cost of emitting carbon. ${ }^{15}$

13 IPCC Fourth Assessment Report: Climate Change 2007 (AR4), http://www.ipcc.ch/pdf/assessmentreport/ar4/syr/ar4_syr.pdf

14 The biofuel challenge, Speech by Peter Mandelson, Brussels, 5 July 2007, http://www.europa-euun.org/articles/en/article 7162 en.htm

15 A pigouvian tax is a tax on an activity that generates negative externalities. The social cost of the activity is not reflected in the cost. 
These policies would not choose methods for reducing emissions, but simply increase the cost of polluting, leaving the market to find the most efficient solutions. If biofuels were an efficient way to reduce carbon emissions, the market would increase supplies in response to the tax. (This approach is fundamentally different than a biofuels mandate, which chooses a technology as opposed to crafting an incentive.).

What would be the impact of a gasoline tax on GHG emissions from transportation? A tax on carbon would take the form of a tax on energy consumption. Studies suggest that a gasoline tax would do relatively little in terms of reducing GHG emissions. One recent study calculated that a 10 cent tax increase on gasoline would decrease U.S. carbon emissions from the transportation sector by about 1.5 percent and decrease total U.S. carbon emissions by about 0.5 percent in the short run. ${ }^{16}$ The effect of increased taxes is likely to be higher in the long run as consumers are more able to reduce consumption and purchase more fuel efficient cars or hybrid vehicles, but this is difficult to determine.

What would be the impact of a cap and trade system on GHG emissions? In a study of the proposed cap and trade system under H.R. 2454: the American Clean Energy and Security Act of 2009 (Waxman-Markey) the Environmental Protection Agency (EPA) found that while the implied carbon tax increases from $\$ 15$ per ton of $\mathrm{CO}_{2}$ in 2015 to $\$ 70$ per ton by 2050, the quantity of petroleum used remains essentially unchanged over the entire period. Instead the use of coal declines significantly and nuclear energy and energy savings make up the majority of the energy deficit left by declining coal. ${ }^{17}$

Why would petroleum use remain unchanged under a cap and trade system while the use of coal would decline? For one, while oil contains carbon, coal contains more. Therefore, burning coal produces higher GHG emissions than burning oil. In the United States, cap and trade policy proposals that are regarded as politically feasible would raise the cost of carbon dioxide by around $\$ 50$ a metric ton, which would increase the price of gasoline by $44 \$$ per gallon. With gas prices around $\$ 2.50$ per gallon at the time of writing this article, such a policy would raise the

\footnotetext{
16 Lucas W. Davis \& Lutz Kilian, Estimating the effect of a gasoline tax on carbon emissions, NBER working paper 14685, http://www.nber.org/papers/w14685

17 U.S. Environmental Protection Agency, EPA Analysis of the American Clean Energy and Security Act of 2009

H.R. 2454 in the 111th Congress, 6/23/09, http://www.epa.gov/climatechange/economics/pdfs/HR2454_Analysis.pdf
} 
price by $18 \%$ to $\$ 2.94$ a gallon, reducing consumption by around $3 \% .{ }^{18}$ By contrast, with coal prices around \$29 per metric ton, ${ }^{19}$ a $\$ 50$ carbon tax would increase prices by $\$ 123$ per metric ton or $427 \%$, Even if coal had a low elasticity of demand like oil, a carbon tax will have a larger impact on consumption and emissions.

In short, if policymakers want to target GHG emissions, the most efficient instruments would not focus on transportation, but on coal. To reduce emissions, it would be most efficient to reduce the consumption of coal, as opposed to spending public resources on adding ethanol to gasoline.

\section{Target: Supporting Farmers}

Many politicians who support biofuels see the fuel as a way to increase farmer incomes and strengthen the rural economy. For example, ethanol supporters argue that ethanol is a prime source of value-added income for American farmers. In addition, supporters argue that biofuel production creates jobs in rural areas. A report for the Renewable Fuels Association concluded, “The ethanol industry has arguably been one of the most significant economic development tools for rural communities in the past several decades." 20 The report adds that economic activity resulting from ongoing ethanol production, construction of new capacity, and R\&D supported nearly 400,000 jobs in all sectors of the economy during 2009. ${ }^{21}$ (Critics have challenged such arguments, suggesting that the corn ethanol tax credit is the "most expensive way to create jobs ever.”) $)^{22}$

Biofuel supporters also argue that by increasing the demand for corn and raising corn prices, ethanol helps lower federal farm program costs. According to the Renewable Fuels Association, in a January 2007 statement, the USDA Chief Economist stated that farm program payments were expected to be reduced by some $\$ 6$ billion due to the higher value of a bushel of

Assuming an elasticity of demand of 0.15

Average coal price of $\$ 26.2$ per short ton in 2007, EIA, Coal prices:

http://www.eia.doe.gov/neic/infosheets/coalprice.html

20 John M. Urbanchuk, "Contribution of the Ethanol Industry to the Economy of the United States, Prepared for the Renewable Fuels Association,” February 12, 2010, p. 6. http://www.ethanolrfa.org/page/-/rfa-associationsite/2009_ethanol_economic_contribution.pdf?nocdn=1

21 John M. Urbanchuk, p. 4.

22 Nathanael Greene, Director of Renewable Energy Policy, National Resources Defense Council, April 7, 2010. http://switchboard.nrdc.org/blogs/ngreene/corn_ethanol_tax_credit_most_e.html 
corn. ${ }^{23}$ However, critics note that higher corn prices translate into higher food prices, especially hurting the poor.

\section{Instrument: Targeted Subsidies}

If we want to save the family farm or reduce rural poverty we need policies that target subsidies to families that farm or to people living in rural areas that are poor. In principle it is not that hard to identify such recipients, but this is rarely done. Indeed, in the U.S. Congress there is fierce resistance to efforts to limit farm subsidies to those below certain income levels. Instead, farm policies often justified in the name of helping poor farmers, often raise target farm prices, an approach which channels the most money to those who grow the most, often wealthy and even corporate farmers.

\section{Separate Goals, Separate Instruments}

Reducing dependence on imported oil, lowering GHG emissions, and supporting farmers are all desirable targets, but they are obviously different goals. In some cases, actions that achieve one of these objectives could contribute towards the other, but in other cases they could work at cross-purposes. For example, a policy that encouraged domestic coal production to produce an oil substitute might successfully reduce oil imports, but actually worsen GHG emissions. Conversely, a policy that increased the cost of using coal in order to reduce carbon dioxide emissions could induce substitution away from coal towards imported oil. A more efficient solution would be to use separate price instruments for each target, as described above, in order to most effectively address each objective.

\section{Can Biofuels Kill Three Birds with One Stone?}

Are three sets of policies really necessary to meet three separate goals? To use an unsavory metaphor, why not kill three birds with one stone by subsidizing and promoting the use of technologies that reduce energy dependence, lower GHG emissions, and strengthen rural economies all at the same time? Biofuels are a technology that have been said to offer promise in all of these areas. First, widespread use of biofuels could conceivably decrease dependence on foreign energy suppliers, especially from OPEC or the Middle East, reducing vulnerability to supply-shocks, macroeconomic fluctuations, and other strategic considerations. In addition,

23 Renewable Fuels association website, http://www.ethanolrfa.org/resource/facts/agriculture/ 
biofuels are said to have the potential to provide a source of energy that releases in aggregate less GHG emissions than gasoline. Second generation biofuels could further reduce emissions. Finally, increasing biofuel production could strengthen rural economies, increasing farmer incomes and creating more jobs.

But despite these potential benefits, biofuels would not be blended with gasoline and consumed without government assistance in the form of tax incentives, subsidies, mandates, tariffs, and targets. As one representative from the U.S. Renewable Fuels Association put it back in 1999, “If we didn't have the tax incentive as a gasoline extender, much of our industry would be out of business."24

However, biofuel subsidies, mandates, and targets are blunt instruments in terms of reaching the specific goals that are used to justify an increased use of biofuels. A mandate to use biofuels is not the most efficient method to increase energy self-sufficiency or meet environmental goals such as reducing GHG emissions. For example, a biofuels mandate will increase the use of biofuels, but this does not ensure that these biofuels will have lower GHG emissions than gasoline unless additional certification systems that require lower emissions are implemented and enforced. If the motivation for biofuels use is energy self-sufficiency and reducing oil consumption, still more certification systems would be required to ensure that the production process for biofuels (which often uses oil to grow feedstocks and process the fuel) is energy efficient.

But there are political benefits to using biofuel mandates instead of more precise instruments. By simply promoting biofuels more generally, a number of different interest groups can be mobilized to provide their support. Farmers, fuel transporters, biofuel producers, politicians from farming areas, automakers, some environmentalists, the energy security community, and many others have supported a general increase in biofuel use. The problem is that non-specific policies will result in none of the policy goals being achieved in an efficient manner.

\section{Moving the Technological Frontier}

24 Jake Thompson, “Iowa Keeps Ethanol as Issue in 2000 Race,” Omaha World Herald (Nebraska), September 6, 1999, p. 1. 
In addition to policies that deal with these three objectives, there is also a case that some technologies that could have beneficial effects might not actually be developed in the presence of taxes alone. Suppose, for example, that today someone created an oil substitute that costs \$75 a barrel and any quantity of the alternative can be produced at that price. Existence of this fuel would be beneficial even if it was never used because it creates a price ceiling for oil. When the price of oil moved above $\$ 75$, demand would switch to the alternative fuel. However, it would be difficult for the inventor of the alternative fuel to capture any benefit when the price of oil was below $\$ 75$. Therefore, the optimal quantity of research and development to create the fuel alternative might not be undertaken privately because the innovator could not capture the full benefit of their discovery. The government should therefore undertake additional research, increasing social welfare, in this case. Alternatively it should subsidize research and development activities by others. In sum, there are reasons for an alternative energy research and technology policy, but these involve precisely targeted approach that aim at improving knowledge about alternative energy technologies rather than simply promoting their use.

\section{Section II - Building Politcal Support}

Though a biofuels mandate does not represent good public policy, it clearly represents a political success. In the efforts to pass a Renewable Fuels Standard in 2005 and the RFS2 in 2007, there was a tremendous amount of political support for these policies. Farmer groups, industry groups, security-minded conservatives, environmentalists, automakers, religious groups and unions all fought for the legislation. In addition, many politicians-particularly farm-state Democrats and Republicans_-supported biofuels. In the United States, ethanol is historically an important issue for presidential candidates. The first state in presidential primary elections is Iowa, which grows corn for the ethanol industry.

Over time, different groups have invoked different reasons to support transportation biofuels, depending on the circumstances of the day. Looking at the history of transportation biofuel policy in the United States, we can observe the changing rationales surrounding its use.

The variety of justifications for supporting biofuels has certainly helped the cause. While the principles of good policymaking require precision and clarity of purpose, the political realities of forming coalitions often benefit from ambiguity. It is helpful when different groups can 
support biofuel for different reasons. While ambiguity can be useful in building consensus, this dynamic can end up creating policies which are unlikely to achieve their stated goals.

While the beneficiaries knew what they stood to gain from the RFS, the costs of the RFS were less clear. The political benefit of a mandate is that it hides the costs of a policy, no one knows exactly who pays or how much. The problem with more specific instruments such as taxes is that they make the costs explicit, making them less politically popular.

Furthermore, a biofuels mandate was often perceived as a more acceptable way to meet environmental or energy-related goals than more controversial policies such as implementing a carbon tax. In this way, the RFS represents a "second best option," an option that supporters may not see as the best policy, but is said to represent some progress on issues of concern.

Finally, it is also important to consider that the 2005 Renewable Fuels Standard and the 2007 revised standard were not passed alone, but as part of larger energy bill packages. Combining different legislative issues into packages creates the potential for trade-offs. These trade-offs can neutralize opposition to any given policy and create a broader coalition.

Below, I expand on each of these arguments with examples from the history of U.S. biofuels policy.

\section{Changing Rationales for Biofuel Use $e^{25}$}

Support for transportation biofuel has existed since the development of the internal combustion engine and the automobile. In 1896, Henry T. Ford's first self-propelled vehicle-the Quadricycle_ran on alcohol. His "Model A" automobiles were equipped with an adjustable carburetor so they could run on gasoline or alcohol. ${ }^{26}$ Ford was not only a pioneer of the factory assembly line and the Model $\mathrm{T}$, but also became an outspoken proponent for the use of transportation alcohol. Ford had a vision of helping farmers by allowing them to grow their own motor fuel. If Model Ts and Fordson tractors could run on alcohol, Ford reasoned, then farmers could profit instead of the Standard Oil Company. ${ }^{27}$

25 This section draws heavily on forthcoming research by Charan Devereaux on the history of U.S. transportation biofuels policy.

26 Hal Bernton, “The Godfather of Gasohol is . . Henry Ford: The Long Struggle for Control over Auto Fuel,” The Washington Post, August 5, 1979, p. B1.

27 Douglas Brinkley, Wheels for the World: Henry Ford, His Company, and a Century of Progress 1903-2003, Viking, New York, 2003, p. 220. 
Over the history of transportation biofuel, different rationales have been forwarded to justify promoting, subsidizing, or mandating biofuel use. In 1906, with agricultural prices falling, farm leaders and alcohol distillers united to push for the removal of the federal tax on industrial alcohol. Many believed that large new markets for alcohol fuels would develop as they looked abroad to Europe, where grain alcohol was more commonly used for fuel. ${ }^{28}$ Creating a domestic alcohol fuel industry was also seen by President Theodore Roosevelt as a trust-busting strategy, a way to create competition for Standard Oil. "The Standard Oil Company has, largely by unfair or unlawful methods, crushed out home competition," Roosevelt declared. "It is highly desirable that an element of competition should be introduced by the passage of some such law . . putting alcohol used in the arts and manufactures on the [tax] free list." ${ }^{29}$ It is remarkable that while more recently OPEC has replaced Standard Oil as the monopolist in question, one of the reasons for promoting bio-fuels has demonstrated such resilience.

There was great public support and high hopes for the 1907 legislation. A Washington Post editorial, declared that if passed, the [Tax] Free Alcohol bill would be "the most beneficent" piece of legislation Congress had delivered in a "double decade."30 "If the new law accomplishes what is hoped," noted the New York Times, "it will be a great boon to farmers and make a revolution in life on the farm." ${ }^{31}$ But cheap gasoline effectively destroyed the idea that new markets for alcohol fuels would develop. ${ }^{32}$ While alcohol sold for 30 cents a gallon, gasoline was selling for as low as 10 cents a gallon. ${ }^{33}$ The idea of using grain alcohol for transportation fuel faded with new discoveries of petroleum, and a growing prohibition movement that curtailed alcohol production for any purpose.

\section{The 1930s Power Alcohol Movement}

The notion of using “power alcohol” rose again as farm prices fell in the late 1920s due to oversupply. As the country passed into the Great Depression, President Franklin D. Roosevelt's

28 August W. Giebelhaus, "Farming for Fuel: The Alcohol Motor Fuel Movement of the 1930s,” Agricultural History, Vol. 54, No. 1, Agricultural History Symposium: Science and Technology in Agriculture (January, 1980), p. 174.

29 "President Flays the Oil Trust: Home Competition Crushed by Unlawful Methods," The Washington Post, May 5, 1906, p. 1.

30 “What about Free Alcohol?” The Washington Post, May 4, 1906, p. 6.

31 "Still on Every Farm to Turn out Alcohol," The New York Times, January 2, 1907, p. 3.

32 August W. Giebelhaus, “Farming for Fuel,” p. 174.

33 Hal Bernton, William Kovarik, and Scott Sklar, The Forbidden Fuel: Power Alcohol in the Twentieth Century, (New York: Boyd Griffin), 1982, p. 10. 
New Deal included an approach to manage these agricultural surpluses. The Agricultural Adjustment Act (AAA) aimed to take farm acreage out of production by paying farmers to reduce their crops and livestock. Instead of supporting reductions in agricultural production, a growing group of "chemurgists" argued that finding new, industrial purposes for farm products would bring the United States renewed economic prosperity (Henry Ford gave financial support to their first conference). Some farm leaders seized on the idea of blending gasoline with alcohol fuel made from surplus grain. The effort became known as the "power alcohol” movement and included critics of the Roosevelt administration's agricultural policies. Looking abroad, a number of European countries - especially Germany-were seen as models for increased use of alcohol in motor fuel. Germany, a petroleum importer, developed and used alternative fuels for strategic reasons.

In 1933, the U.S. Congress considered legislation to require the compulsory use of alcohol with gasoline. The Department of Agriculture supported the legislation, noting that corn would provide abundant supplies of raw material for the production of alcohol. ${ }^{34}$ However, not everyone supported power alcohol. The American Petroleum Institute (API) launched a campaign against it noting "prompt action is necessary to counteract the aggressive and misleading propaganda of the proponents of the blending schemes.”35 The American Automobile Association (AAA) opposed alcohol fuels as economically unsound. At the height of the power alcohol movement, in the late 1930’s, over 2,000 service stations in eight Midwestern states sold an alcohol-gasoline blend. ${ }^{36}$ But sales dropped rapidly as grain prices rose-alcohol could not compete with the cost of gasoline.

\section{Biofuel in the 1970s}

Interest in the use of grain alcohol for motor fuel receded after the 1930s. The idea revived briefly in the 1950s during a period of agricultural surplus, but did not appear again until the 1970s. For many years, the United States had fulfilled its own needs for oil but by 1973, the United States imported about 36 percent of its petroleum, and petroleum supplied at least 50

\footnotetext{
“Alcohol for Motors,” The Washington Post, May 10, 1933, page 6.

Hal Bernton, The Washington Post, August 5, 1979, p. B1.

Joseph DiPardo, “Outlook for Biomass Ethanol Production and Demand,” Energy Information Administration, U.S. Department of Energy, 2000, p. 2.
} 
percent of U.S. energy needs. ${ }^{37}$ About 17 percent of total petroleum use came from OPEC, the Organization of Petroleum Exporting Countries, with 5 percent of total petroleum use coming specifically from the Persian Gulf countries. In October 1973, the Arab members of OPEC announced an oil embargo targeting the United States in retaliation for support of Israel in the 1973 Arab-Israeli War. OPEC also announced a 70 percent increase in the reference price of oil, setting off a global upward spiral in oil prices. As gas lines formed at service stations, the United States became aware of its growing dependence on oil imports.

Three weeks after the announcement of the oil embargo, during the height of the Watergate controversy, President Richard M. Nixon announced Project Independence with the goal of ending American reliance on foreign oil by 1980. "By the end of this decade, we will have developed the potential to meet our own energy needs without depending upon any foreign energy sources,” Nixon said. ${ }^{38}$ Nixon's plan introduced the political idea of energy independence in the United States.

President Jimmy Carter sharpened the national focus on the “energy crisis,” calling it "the moral equivalent of war.” In a televised 1977 speech, Carter noted, “The oil and natural gas we rely on for 75 percent of our energy are running out. . . Our nation's independence of economic and political action is becoming increasingly constrained." ${ }^{39}$ With oil imports at 44 percent, Carter set a target of holding them to 30 percent. The President also announced plans to remove federal price controls from domestic oil in an effort to reduce dependence on oil imports. In addition, the federal government adopted a series of policies to encourage the use of alternative fuels.

In addition to changes in energy policy, the government's approach to agriculture policy was also shifting. Nixon's agriculture secretary Earl Butz, who came of age during the Depression-era policies that restricted agricultural production, instituted a new approach to federal farm policy. In 1974, he encouraged farmers to plant "from fencerow to fencerow," leading to more intensive farming practices. As agricultural production grew, grain prices dropped-but energy costs continued to rise.

U.S. Energy Information Administration, http://www.eia.doe.gov/emeu/mer/pdf/pages/sec3_7.pdf Robin Toner, "Proposal Is Latest U.S. Reaction to Concerns That Wax and Wane,” The New York Times, May 17, 2001, p. A1.

39 President Jimmy Carter, April 18, 1977. http://www.pbs.org/wgbh/amex/carter/filmmore/ps_energy.html 
Meanwhile, farm states were developing an interest in fuel ethanol. In 1971, the corngrowing state of Nebraska formed a committee to study ethanol as a possible solution to low grain prices. Two committee advisers organized a series of road tests, concluding that 10 percent alcohol blends could be used successfully. Nebraska and 12 other states formed a National Gasohol Committee to promote the fuel. ${ }^{40}$

Some members of Congress were also becoming interested in gasohol as a domestically produced fuel. One of the earliest supporters was Nebraska Senator Carl Curtis (R). Other supportive farm state senators included Birch Bayh (D-IN), Charles Percy (R-IL), Robert Dole (R-KS), and Frank Church (D-ID). ${ }^{41}$

There was also corporate interest in alcohol fuel. Dwayne Andreas, Chairman and CEO of the agricultural processing company Archer-Daniels-Midland Company (ADM), believed that the United States would need to develop greater reliance on domestically produced fuel. ADM spent \$20 million constructing a commercial fuel-alcohol plant. Though the plant was completed in 1977, gasohol was too expensive to compete with gasoline. ${ }^{42}$

Unlike in the 1930s, when the American Automobile Association (AAA) lobbied against alcohol fuels, in the 1970s, AAA enthusiastically supported gasohol. But some oil companies remained decidedly against gasohol and federal support of the fuel, arguing that it took more energy to produce grain alcohol than the amount of energy it could generate. Ford Motor Company and General Motors warned that gasoline-alcohol mixtures could cause corrosion of motor parts and that car owners might have to spend up to $\$ 75$ to adjust their carburetors. ${ }^{43}$ Worldwatch Institute published a report voicing concerns that a large gasohol program would put pressure on global grain prices, hurting developing countries. ${ }^{44}$

\section{The 1978 Tax Exemption and the 1980 Tariff}

A powerful piece of biofuels legislation was passed in 1978 when Congress exempted gasohol from the federal excise tax. Sponsored by Senator Robert Dole (R-KS), the Energy Tax Act of 1978 established a 4-cents-per-gallon exemption from the federal highway tax for motor

\footnotetext{
40 Walter S. Mossberg, "Can U.S. Reduce Imports with Gasohol? Some Say Yes, But Officials are Dubious,” The Wall Street Journal, July 12, 1978, p. 39.

41 Bernton et. al., The Forbidden Fuel, p. 101.

42 Sue Shellenbarger, The Wall Street Journal, January 15, 1981, p. 1.

43 Walter S. Mossberg, “Can U.S. Reduce Imports with Gasohol?” The Wall Street Journal, July 12, 1978 , p. 39.

44 Lester Brown, “Food or Fuels: New Competition for the World’s Cropland,” Worldwatch, March, 1980.
} 
fuels blended with at least 10 percent alcohol derived from agricultural products. The law amounted to a 40-cents-per-gallon subsidy for every gallon of ethanol blended into gasoline. The creation of the tax exemption, which remains in place today, was crucial in the development of the alcohol fuels industry. By the spring of 1980, there were additional alcohol subsidies in about 27 states. By 1981, gasohol was sold at more than 9,000 filling stations in 45 states. $^{45}$

Though gasohol was marketed as a U.S.-grown fuel, as its use increased, imports of Brazilian sugar ethanol also grew. By the end of 1980, U.S. consumption of ethanol was 120 million gallons - 62 million gallons were produced in the United States and 58 million gallons were imported. ${ }^{46}$ ADM had about 75 percent of the U.S.-produced fuel alcohol market. ${ }^{47}$

Advocates of domestically produced alcohol fuel in the United States were not pleased by the increasing imports, arguing that the tax exemption was designed to spur domestic production, enhance energy security, and create benefits for U.S. farmers-not grow imports. In May 1980, Senator Birch Bayh (D-IN) asked the Treasury Department to examine methods of denying the federal tax exemption to imported ethanol. ${ }^{48}$

In its October 1980 report, the Treasury Department indicated that no direct action should be taken to eliminate imported alcohol fuel from the American market. The report concluded that Brazilian ethanol imports had helped the growth of the U.S. industry and that a tariff on imported alcohol would violate the General Agreement on Tariffs and Trade (GATT). ${ }^{49}$ The Justice Department and the Special Trade Representative also opposed the tariff, as did House Subcommittee on Trade Chairman Charles A. Vanik (D-OH) who wrote that it "contributes to the monopoly control of the major domestic producer (the Archer-Daniels-Midland Company).”,50

Despite these conclusions, Congress took action to curb ethanol imports. Though the tax credit could not be denied to foreign ethanol, supporters of the U.S. industry advocated

45 Ward Sinclair, "Fuel for the Future; Use of a Vital Food Commodity for Gasohol Raises Hopes, Questions," The Washington Post, June 12, 1981, p. A10.

46 Migdon R. Segal, “Gasohol: The Alcohol Fuels,” The Library of Congress, Congressional Research Service, Issue Brief No. IB74087, updated November 5, 1981, p, 5.

47 ADM's market share in Sue Shellenbarger, The Wall Street Journal, January 15, 1981, p. 1.

48 Stuart Mieher, “Growing U.S. Gasohol Demand Triggers Surge in Inflow of Brazilian Fuel Alcohol,” The Wall Street Journal, June 18, 1980, p. 15.

49 Migdon R. Segal, “Gasohol: The Alcohol Fuels,” 1981, p. 8.

50 Cass Peterson, "Strauss Expected to Join Board of Big Grain Processor," The Washington Post, January 14, 1981, p. A4; Clyde H. Farnsworth, “Farm Lobby's Gasohol Victory,” The New York Times, Dec. 1, 1980, p. D2. 
establishing a tariff to offset the credit. Senator Bob Dole sponsored a bill to increase the duty on ethanol imports by 40 cents a gallon.

Initially, President Carter opposed a tariff on fuel alcohol. However, in a White House luncheon on October 7, 1980-less than a month before the presidential election in the race with Republican Ronald Reagan-ADM's Dwayne Andreas reportedly promised that he would announce plans for a new alcohol fuel plant in Iowa, a key state for the Carter campaign, if the administration supported the ethanol tariff. Carter's re-election campaign chairman Robert Strauss urged that the president immediately impose the tariff. ${ }^{51}$ In a letter obtained by The New York Times dated October 29, five days before the election, President Carter told his Treasury Secretary to protect the U.S. ethanol industry “immediately, by administrative means if possible, by legislation if necessary."52

Soon after Carter lost his re-election bid, the import duty for fuel ethanol was passed by Congress as part of the Omnibus Reconciliation Act of 1980. It was signed by Carter on December 5, 1980. A few months later, ADM postponed the plans for the Iowa plant indefinitely. The plant was never built. ${ }^{53}$

\section{Ethanol Use Decreases as Oil Prices Fall}

The price of oil was dropping. As prices fell at the pump during the mid-1980s, the demand for ethanol decreased-even after a 1985 bumper corn crop. By the end of 1985, only 74 of 163 commercial ethanol plants remained in operation. ${ }^{54}$ In 1986, the price of oil dropped from $\$ 27$ to \$10 dollars a barrel and gasoline prices averaged 55 cents a gallon, compared to the $\$ 1.40$ per gallon cost of producing ethanol.

As the price of oil dropped and agricultural production increased, some ethanol supporters emphasized that efforts to stimulate the ethanol industry could help solve the problems of agricultural overproduction and reduce the cost of government agricultural price support

51 “Cash, Connections Fuel Cause PAC Funds to Lawmakers Intended to Spur Gasohol Boom,” The Washington Post, December 8, 1985, p. H07.

52 Clyde H. Farnsworth, “Farm Lobby's Gasohol Victory,” The New York Times, December 1, 1980, p. D2.

53 Jim Drinkard, "Economics Undermine Gasohol Market,” The Associated Press, March 1, 1981. Douglas Martin, "Budget Cuts, Weak Market Hurt Gasohol,” The New York Times, December 14, 1981, p. A1. ${ }^{54}$ Office of Energy, US Department of Agriculture, "Fuel Ethanol and Agriculture: an Economic Assessment,” Agriculture Economic Report No. 562, Washington DC, August 1986, p. iv. 
programs by increasing the demand for grain. In August 1986, the USDA's Office of Energy considered the impact of increased fuel ethanol production. "Any benefits of higher income to farmers would be more than offset by increased government costs and consumer food expenditures," the report concluded. ${ }^{55}$

\section{Ethanol and the Environment}

In the 1980s and 1990s, corn-based ethanol found new purposes. One was increasing gasoline performance. Since the 1920s, lead had been used to boost gasoline octane ratings, reducing "engine knocking" and allowing the use of more powerful high-compression engines. But in 1985, the EPA ruled that 90 percent of lead must be removed from gasoline due to environmental and health risks. As a replacement, fuel blenders could boost gasoline octane ratings by adding ethanol or methyl tertiary butyl ether (MTBE), made from methanol and a byproduct of gasoline refining.

Ethanol was also seen by some as a strategy to reduce urban air pollution. The Clean Air Act Amendments of 1990 (CAAA) required the most polluted urban areas to use gasoline with a minimum oxygen content in order to improve air quality. It was argued that adding "oxygenates" to gasoline would allow the fuel to burn more completely, reducing carbon monoxide emissions and ground-level ozone. Ethanol was not the only possible oxygenating additive-MTBE also functioned as an oxygenate.

The oil industry favored MTBE over ethanol because it was often produced in the same refineries as gasoline and was easier to transport (ethanol can not be transported through petroleum pipelines because it separates from gasoline in the presence of water). But in 1994, under President Bill Clinton, the EPA ruled that ethanol must make up at least 30 percent of gasoline oxygenates. The petroleum industry filed suit, challenging the mandate. In 1995, a court ruling determined that the EPA had exceeded its statutory authority and could not require the use of ethanol over MTBE.

In the end, the CAAA requirements increased the use of both ethanol and MTBE. MTBE was a more popular additive, accounting for about 3 percent of the total transportation fuel consumption by 1995, while ethanol was less than 1 percent. It was estimated that the excise tax exemption for alcohol blenders had reduced revenues to the Highway Trust Fund by $\$ 7.1$ billion

55 Office of Energy, US Department of Agriculture, August 1986, p. i. 
from fiscal year 1979 to $1995 .^{56}$ In 1995 , a Prudential Securities analyst estimated that ethanol production had earned ADM nine percent of its profits in 1995, over $\$ 75$ million. ${ }^{57}$ Interestingly, some argued that by the mid-1990s, the use of oxygenating additives was becoming unnecessary. Starting in 1994, the car industry began installing oxygen sensors in new vehicle engines, which adjusted the air-to-fuel ratio, achieving a cleaner burning engine without additives. ${ }^{58}$ But many older cars were still on the roads, and the CAAA requirements remained in place. Observers noted that without the regulations and incentives, much of ethanol's market would likely disappear since it tended to be more expensive than gasoline. ${ }^{59}$

The 1990s saw another development that impacted the ethanol industry. In 1993, a credit was created for companies that produced flexible fuel vehicles-cars that could run on either an 85 percent ethanol fuel blend (E-85) or regular gasoline. Popular with both Democrats and Republicans, especially those from corn ethanol and car-manufacturing states, the legislation allowed automakers to receive credit for meeting fuel economy standards by producing the flex fuel vehicles even if drivers used only regular gas. Supporters hoped that new infrastructure investments would follow, creating more E85 pumps across the country.

\section{Creating the 2005 Renewable Fuels Standard}

When Republican President George W. Bush took office in January 2001, energy policy was high on the list of priorities. "America in the year 2001 faces the most serious energy shortage since the oil embargoes of the 1970's,” warned the National Energy Policy Development Group. ${ }^{60}$ One of the main thrusts of the president's national energy plan was to create "diversity” in energy supplies. The last time comprehensive energy legislation had passed was 1992.

A new energy bill was introduced in Congress in 2001, but efforts stalled. In 2002, the energy bill died after long conference. In 2003, the energy bill was resurrected. Versions were passed in both the House and the Senate that included an annual mandate to blend ethanol into

56 US General Accounting Office, Tax Policy - Effects of the Alcohol Fuels Tax Incentives, Report to the Chairman, Committee on Ways And Means, House of Representatives, March 6, 1997, p. 3.

57 Peter Carlson, “Chairman across the Board,” The Washington Post, July 14, 1996, Sunday Magazine, p. W13.

58 Alan Murray “Political Capital: U.S. Energy Needs Languish as Ethanol Intoxicates Congress,” The Wall Street Journal, October 7, 2003, p. A4.

59 Brent D. Yacobucci and Jasper Womach, Fuel Ethanol: Background and Public Policy Issues, Congressional Research Service, Updated March 22, 2000.

60 National Energy Policy Development Group, National Energy Policy: Reliable, Affordable, and Environmentally Sound Energy for America’s Future, May 2001, p. viii. 
gasoline (the House version mandated five billion gallons of ethanol by 2015; the Senate mandated the same amount by 2012). Proponents argued expanded ethanol use would reduce U.S. dependence on imported oil. Bob Dinneen, president of the Renewable Fuels Association, said the ethanol mandate would create about 214,000 jobs. ${ }^{61}$ Senate leaders characterized the ethanol provision as a "political driver" of the energy bill. ${ }^{62}$

Some believed the 2003 energy bill should also include a waiver to partially protect oil and chemical companies from MTBE lawsuits. A number of cities had filed suits against the additive's producers, seeking damages for water contamination. Observers said the energy bill became a battleground for Midwest Senators who supported ethanol and Southern House members who supported limited liability for MTBE. In the end, the compromise version of the 2003 energy bill included both the ethanol mandate and the MTBE liability waiver. ${ }^{63}$ Though the 2003 energy bill passed in the House, the Senate filibustered. Some believed that revoking the MTBE waiver could end the filibuster in the Senate and bring the energy bill to a vote. But House Majority Leader Tom DeLay (R-TX), showed no interest in dropping the MTBE provisions. The energy bill never received a Senate vote and would not pass in 2003.

Meanwhile, as gas prices continued to rise (crude oil was at about \$54 a barrel, up from about \$36 the year before), a group of Republicans (and some Democrats) was organizing to decrease U.S. dependence on foreign oil as a matter of national security. In March 2005, 26 former national-security officials wrote the president. "We ask that you to launch a major new initiative to curtail U.S. consumption through improved efficiency and the rapid development and deployment of advanced biomass, alcohol, and other available petroleum fuel alternatives," their letter read, suggesting funding at $\$ 1$ billion over the next five years. ${ }^{64}$ Biofuel supporters said the war in Iraq and concerns about terrorism had increased public interest in reducing dependence on foreign oil.

A growing coalition called Set America Free advocated federal research dollars and tax credits to encourage the development of vehicles that ran on alternative power. Some environmental groups such as the Natural Resources Defense Council supported this use of

\footnotetext{
61 John J. Fialka, “Senate Votes for More Ethanol in Gas,” The Wall Street Journal, June 6, 2003 , p. B2.

62 John J. Fialka and Shailagh Murray, "Rush Is On to Rescue Energy Bill --- Filibuster Over Additives Stalls \$31 Billion Plan; Bush, Republicans Scramble,” The Wall Street Journal, November 24, 2003, p. A3.

63 Dan Morgan, "Nursing a Fragile Energy Bill; Protection for Fuel-Additive Makers a Sticking Point in Senate,” The Washington Post, November 24, 2003, p. A05.

64 http://www.energyfuturecoalition.org/pubs/National\%20Security\%20Letter.pdf
} 
federal funding. Set America Free also included evangelical Christian groups and consumer organizations. Meanwhile, the United Auto Workers (UAW) began pushing for a federal program to encourage U.S. carmakers to develop alternative-fuel technologies. Traditionally, the UAW had opposed efforts to boost federal gas mileage standards due to concerns about job losses. But union leaders predicted biofuels could bring more jobs. "It's good for America to reduce our consumption of oil, and it could create thousands of good jobs for American workers," said UAW President Ron Gettelfinger. ${ }^{65}$

Many state officials were supportive of increased ethanol use. In April 2005, as the average retail gasoline price hit a record at that time of $\$ 2.28$ per gallon, the Governor's Ethanol Coalition, representing 30 U.S. Governors, released a report endorsing the use of 8 billion gallons of ethanol by $2012 .^{66}$

But the oil industry and members of Congress from oil-producing states fought broader ethanol use. The American Petroleum Institute had agreed to support a mandate of five billion gallons a year by 2012 during negotiations in 2004. "We think that's adequate," said the Institute's Ed Murphy. "After that, it's up to them to prove they can compete with other fuels.” But observers said the petroleum industry was losing ground. According to the Wall Street Journal, “the [oil] industry's clout might be offset by the new appeal of ethanol to environmental groups and to national-security-minded conservatives."

Negotiators worked to iron out the differences between the House and Senate versions of the bill. In the end, the conference report set the biofuels mandate at 7.5 billion gallon by 2012 . Lawmakers resolved one of the most contentious issues by agreeing not to protect MTBE manufacturers from defective product lawsuits. (This decision would essentially end the use of MTBE as a gasoline additive). The legislation also extended the provision giving automakers fuel economy credit for producing flex fuel E85 vehicles.

In August 2005, after five years of effort, President Bush signed the Energy Policy Act of 2005, known as EPACT, the first omnibus energy legislation enacted in more than a decade. Farm groups celebrated the newly created Renewable Fuels Standard (RFS) of 7.5 billion gallons by 2012. Some observers say that though a broad coalition of supporters for the ethanol mandate

65 “Is That a Flex-Fuel You're Driving?” Solidarity: The Magazine for UAW Members, March-April, 2006. US Production Mandate To Reduce Oil Dependency,” The Wall Street Journal, April 12, 2005, p A2. 
was important, the most crucial group was farm state Senators. "For more than five years, corn growers have pushed for comprehensive national energy policy that includes an RFS," said National Corn Growers Association (NCGA) President Leon Corzine. "By working side by side with industry and government we have built the ethanol industry from the ground up.”68

\section{Expanding the Renewable Fuels Standard}

As oil prices continued to rise, the Governors’ Ethanol Coalition (now representing 37 state governors) pushed for an expansion of the RFS. In a December 2006 letter, they applauded the president for "endorsing ethanol as the primary means to . . . end the nation's addiction to oil." 69 Also supporting an increase in ethanol production were U.S. automakers General Motors, Ford, and Chrysler. Car executives had pushed for greater availability of E85 fuel. The cost to equip a vehicle to run on E85 was low-\$25 to \$125-and in return, automakers received fuel economy credit, allowing them to increase their fleets' average fuel economy. Observers said executives preferred to build flex-fuel cars rather than adopt stricter fuel-economy standards, which required a higher investment from automakers.

In his January 2007 State of the Union address, President George W. Bush set a goal to reduce gasoline consumption in the United States by 20 percent over 10 years. To partially offset the use of gasoline, Bush said, the United States would increase its use of renewable and alternative fuels to 35 billion gallons by 2017 for national energy security and environmental reasons.

In March 2007, meeting with Bush for the second time in four months, the CEOs of GM, Ford, and Chrysler pressed the president to extend access to biofuels, promising to make half of their vehicles flex-fuel by 2012. "If the goal is to reduce oil imports and improve the environment, the opportunity is first of all in ethanol [and] biodiesel,” said GM's Rick Wagoner. However, more biofuel pumps were needed, he noted. Of the nation's 170,000 gas stations, only 2,000 had pumps for E85 or biodiesel. Investments to increase the number of E85 pumps would come not from automakers, but government and fuel providers. "We are willing to lead the way,"

\footnotetext{
68 National Corn Growers Association, “Corn Growers Near Victory with House Passage of Energy Bill; National Corn Growers Association Calls Bipartisan Bill a Win for All Americans,” July 28, 2005.

69 Governors' Ethanol Coalition, Letter to President George W. Bush accompanying the report Ethanol from Biomass: How to Get a Biofuels Future, December 27, 2006.
} 
the automakers said. "But we need government and fuel providers to increase infrastructure before we can make a meaningful impact."70

On Capitol Hill, ethanol was an increasingly popular issue. As of May 2007, more than 145 bills had been introduced in the last year to help boost ethanol production-no other subject had garnered as much legislative attention. ${ }^{71}$ The U.S. ethanol industry was growing; 81 new plants were under construction and 650 million bushels of Iowa corn were processed into ethanol in 2006. In addition, some U.S. diplomats hoped that an increased RFS would raise demand for agricultural products, holding down U.S. subsidies, satisfying demands in the Doha round of trade talks.

But the National Petrochemical and Refiners Association argued that current ethanol policy was distorting markets and opposed any increase to the RFS. Opposition was spreading to food producers, environmental groups, religious groups, health groups, and anti-hunger groups. As ethanol production soared in 2005 and 2006 so had the price of corn, reaching its highest level in a decade. A group of major food companies declared that requiring greater use of ethanol would affect their "ability to produce competitively available, affordable food."72 (However, some argued that increasing food prices had little to do with biofuels production and that food companies saw biofuels as an easy target.) Some environmental groups argued that more effective steps were needed to combat global warming. Greenpeace noted that limits on carbon emissions would be a far better way to reduce greenhouse gases than boosting ethanol use.

Congress expanded the Renewable Fuels Standard in the Energy Independence and Security Act of 2007, which was signed by President Bush in December 2007. According to one account, "lawmakers saw a public policy trifecta: a chance to boost rural economies, decrease oil imports and reduce greenhouse gas emissions." ${ }^{73}$ The revised RFS called for 36 billion gallons of renewable fuels to be produced by 2022. Of that total, 15 billion gallons would come from traditional corn-based ethanol, and 21 billion gallons would come from “advanced biofuels” like cellulosic ethanol.

70 “Carmakers Push More Use of Alternative Fuels,” The New York Times, March 27, 2007, p. C6. Also see Harry Stoffer, "Energy Message is a Mixed Bag for Automakers,” Automotive News, January 29, 2007, p. 3.

71 Jeffrey H. Birnbaum, “It's a Good Time to Be The Hill's Mr. Ethanol,” The Washington Post, May 15, 2007, p. A13.

72 Lauren Etter, "Ethanol Craze Cools: As Doubts Multiply Claims for Environment, Energy Use Draw Fire; Fighting on the Farm,” The Wall Street Journal, November 28, 2007, p. A1.

73 Jim Snyder, “Oil Lobby Looks to Delay Deadlines for New Renewable Fuels Standard,” The Hill, February 13, 2008, p. 14. 


\section{Strategic Ambiguity}

As discussed above, government support for transportation biofuels is an idea that has recurred since the development of the automobile. There has been a variety of rationales for this support including addressing agricultural surpluses or low agricultural prices, reducing the cost of federal price support payments to farmers, helping rural economies, increasing energy security by reducing reliance on oil imports, responding to high oil prices or limited oil supply, addressing environmental concerns (ranging from urban smog to carbon emissions), increasing engine performance, helping carmakers and autoworkers, and creating competition in the energy market.

The wide variety of goals surrounding biofuels has helped the cause. Why? Because biofuels could be all things to all people. A lack of precision about policy goals, sometimes known as constructive or strategic ambiguity, can be very useful when advancing a political purpose. The ambiguity surrounding the question of why government should support transportation biofuels helped create the necessary support to facilitate the passage of biofuel mandates. In the creation of the 2005 Renewable Fuels Standards and the 2007 revised standard (RFS2), the lack of clarity surrounding exactly what a mandate would accomplish proved to be very useful in building a successful political coalition. A major appeal of an RFS is that it could be supported by a number of groups for different reasons.

Different groups had different motivations for throwing their support behind biofuels and the RFS. Corn farmers supported a biofuels mandate to increase demand for corn. Domestic biofuels companies supported a Renewable Fuels Standard because it would grow their industry. Some environmental groups supported increased use of biofuels as a way to encourage carmakers to adopt newer technologies. Some also believed that biofuel use could decrease the release of greenhouse gases which contribute to global warming. The United Autoworkers believed an RFS would create jobs. US automakers hoped to gain credits for meeting fuel efficiency standards. A group of conservative Republicans described as “a who’s who of right-leaning military hawks” by The Washington Post, wanted to decrease U.S. dependence on foreign oil as a matter of national security. ${ }^{74}$

74 Greg Schneider, “An Unlikely Meeting of the Minds; For Very Different Reasons, Groups Agree on Gas Alternatives,” The Washington Post, March 31, 2005, p. E01. 
Because so many benefits were promoted, it appeared the legislation would kill many birds with one stone (to repeat the unsavory metaphor). But a lack of clarity about goals can lead to problems - ambiguity can generate subsequent controversy. In the case of the RFS and RFS-2, concerns about the environmental impact of the legislation grew. Producing more corn would require the use of more water resources and petroleum-based fertilizers, which could be damaging to the environment. Concerns also grew that increased corn production would cause more land to be cleared for agricultural purposes, releasing more carbon into the atmosphere. As a result, in the 2007 revised RFS, language was included requiring corn ethanol production to emit 20 percent less greenhouse gases than gasoline and advanced biofuels to release 50 percent less GHG (with cellulosic biofuels releasing 60 percent less GHG). When determining the GHG emission profile of fuels under the RFS-2 program, the EPA was required to consider "significant indirect emissions.” Debate grew about how the EPA would consider such emissions and who would be impacted by the decision. Though often touted as helping the environment, biofuels are not the most efficient or direct way to lower green house gas emissions. Disappointment was inevitable.

\section{The Problem with Precision -- Explicit Costs vs. Hidden Costs}

In the first part of this paper, I described a hallmark of good policymaking-designing a precise instrument to meet each desired policy target. As discussed, the most precise instrument for meeting targets such as increasing energy independence and decreasing carbon emissions is implementing a tax. Despite the policy benefits of creating a precise instrument such as a tax, it is often not politically advantageous to do so. From a political standpoint, the problem with taxes is that they make the cost of reaching a goal transparent and explicit. When the cost is transparent, it becomes clear who is paying for the policy and how much. It is more politically advantageous to hide the true cost of any policy, so that no one knows exactly who is paying for the policy or how much it costs. This way, there are fewer explicit “losers.” As one 1970s observer put it, “Gasohol is politically wonderful because the benefits are concentrated on some politically important groups and the bad effects are spread out all over the place.”75

75 Scott King of the investment firm F. Eberstadt and Co., quoted in Paul Blustein, "Despite Political Hoopla about Gasohol, Some Experts Call Program Impractical,” The Wall Street Journal, January 10, 1980 , p 18. 
Biofuels supporters gained a political advantage by pursuing the idea of a mandate. A great political benefit of creating a mandate is that unlike a tax, no one knows exactly what it will cost. As a result, once a mandate is established, it is often not difficult to increase it since the costs of doing so are unclear. When the idea of a biofuels mandate was being discussed in Congress in 2003, not all were enthusiastic. “The problem with this mandate is that it isn't clear that it will ever stop,” said Robert Slaughter, president of the National Petrochemical and Refiners Association. "What's going to happen with this every year from now on is that somebody is going to put in a bill to increase the percentage [of biofuel in gasoline].,76

The total cost of the U.S. Renewable Fuels Standard is impacted by a number of factors including the excise tax exemption, subsidies to corn growers, the tariff on imported biofuels, changes in the price of food and animal feed, changes in gasoline prices, and environmental damage from using water resources and petroleum-based fertilizers to grow biofuel feedstocks. The nature and extent of these costs are often debated. In 2008, Richard Wiles, executive director for the Environmental Working Group, noted, “This year's 9 billion gallon RFS mandate will cause an estimated 100 million tons of soil erosion and put 300,000 tons of nitrogen fertilizer into Midwestern waters. Thanks largely to the ethanol mandate and an excessively wet spring, pollution levels in the Gulf of Mexico are expected to reach record levels, with a dead zone the size of Massachusetts."77 Others argue that the environmental impact of growing biofuel feedstocks is not nearly as problematic as such statements would suggest. In short, is difficult to calculate how much a biofuels mandate costs and who bears the burden.

\section{The "Second-Best" Option}

In addition to hiding costs, biofuel use is sometimes perceived as a more acceptable or politically palatable way to meet environmental or energy-related goals than more controversial policies such as implementing a carbon tax, a gas tax, or tougher fuel economy standards. In this way, policies such as the U.S. Renewable Fuels Standard and the use of E85 flex-fuel automobiles represent "second best options" for some, options that were not seen as the optimal policy, but appeared to represent some progress on issues of concern. As Anne Korin, an

\footnotetext{
76 Robert Slaughter quoted in John J. Fialka, “Senate Votes for More Ethanol in Gas,” The Wall Street Journal, June 6, 2003, p. B2.

77 “Renewable Fuels Standard Under Fire,” California Farmer, June 20, 2008. http://californiafarmer.com/story.aspx?s=17923\&c=8
} 
organizer of the Set America Free Coalition, noted, "You have a lot of people out there that would rather wait for a perfect solution. We don't have the time to wait for perfect solutions.”78

For example, in 2005, some environmental groups saw flex fuel vehicles as a workable, achievable option when compared to increasing fuel economy standards-a policy long opposed by car makers and labor unions. According to the Wall Street Journal, some environmentalists had concluded that after years of losing battles in Congress to increase fuel-economy standards, it was time to work with auto companies. "We needed to be much more creative," said Ashok Gupta, director of the Natural Resources Defense Council's (NRDC) air and energy program. ${ }^{79}$ Providing funds to promote alternative energy vehicles was seen as "enactable” in the short term. “Our belief is that there is a lot of merit to policies that I guess you'd call 'carrot and stick' policies," said David Doniger, policy director for the NRDC Climate Center. "You need the limits on pollution . . . but in addition we recognize that the industry could benefit from some incentives to convert technology more quickly and at lower cost.” Such legislation "may be both more enactable and more successful than focusing only on the limits, or on the stick, so to speak," Doniger said. ${ }^{80}$

Some argue that the Renewable Fuels Standards also represented a way for the Bush administration to say it was dealing with the issue of climate change. In 2005, European leaders were pressing the administration to take stronger action against greenhouse gases in the lead up to the Group of Eight summit. Pressure was also growing from some key Bush administration allies for tougher action on global warming. The White House continued to question some of the most serious predictions about global warming, oppose the Kyoto Protocol, and reject new regulations to reduce greenhouse gases. Supporting the RFS was one way the White House could support environmental goals.

When an increase in the RFS was passed in the 2007 Energy Independence and Security Act, the President touted its environmental benefits. "Taken together," the President said of the legislation, “all these measures will help us improve our environment. It is estimated that these

78 Quote from Korin in John J. Fialka and Jeffrey Ball, “Unlikely Allies Fight U.S. Oil Dependence - Bipartisan Network to Press for Reduced Consumption, Quicker Development of New Fuels,” The Wall Street Journal, March 28, 2005, p. A4.

79 Quote from Gupta in John J. Fialka and Jeffrey Ball, “Unlikely Allies Fight U.S. Oil Dependence - Bipartisan Network to Press for Reduced Consumption, Quicker Development of New Fuels,” The Wall Street Journal, March 28, 2005, p. A4.

80 Greg Schneider, “An Unlikely Meeting of the Minds; For Very Different Reasons, Groups Agree on Gas Alternatives,” The Washington Post, March 31, 2005, p. E01. 
initiatives could reduce projected $\mathrm{CO} 2$ emissions by billions of metric tons. At the UN climate change meeting in Bali last week our nation promised to pursue new, quantifiable actions to reduce carbon emissions. Today we're doing just that. The legislation I'm signing today will lead to some of the largest CO2 emission cuts in our nation's history." Not everyone agreed. "Bush is betting the farm that the best alternative fuel for the foreseeable future is corn ethanol. It isn't,” declared Joseph Romm, former Acting Assistant Secretary of Energy for Energy Efficiency and Renewable Energy during the Clinton Administration. ${ }^{81}$

\section{A Package Deal}

It is also important to consider that the 2005 Renewable Fuels Standard and the 2007 RFS-2 were not passed alone, but as part of larger energy bill packages. Combining different legislative issues into packages creates the potential for trade-offs. These trade-offs can neutralize opposition and create a broader coalition. For example, in initial negotiations for an energy bill in 2003, a biofuels mandate was considered alongside a proposal that was favorable to the oil industry-limited liability for court cases involving MTBE. Though the 2003 energy bill did not pass, the discussions helped gain some initial oil industry support for (or at least, reduced resistance to) a biofuels mandate. ${ }^{82}$ The American Petroleum Institute agreed to support a mandate of five billion gallons a year by 2012 during energy bill negotiations in 2004. "We think that's adequate,” said the Institute's Ed Murphy. “After that, it's up to them to prove they can compete with other fuels." 83

\section{Conclusion}

81 Joseph Romm, “The Fuel on the Hill,” Salon.com, December 20, 2007. http://www.salon.com/news/feature/2007/12/20/biofuel/index.html

82 Bob Slaughter, president of the National Petrochemical and Refiners Association, whose members included MTBE makers, said it would be unfair to strip out the MTBE provisions from the bill because they were included as part of a broad compromise. The energy legislation, he noted, included a requirement that the gasoline industry double its use of corn ethanol fuel. The National Petrochemical and Refiners Association had long opposed such a mandate but agreed to support it in return for the liability waiver and other concessions for MTBE's makers. Dan Morgan, "Nursing a Fragile Energy Bill; Protection for Fuel-Additive Makers a Sticking Point in Senate,” The Washington Post, November 24, 2003, p. A05. Also see

83 John J. Fialka, "Governors Seek Wider Ethanol Use -- Coalition Backs Expanding U.S. Production Mandate To Reduce Oil Dependency,” The Wall Street Journal, April 12, 2005, p A2. 
While good policy-making demands precision about policy targets and instruments, it is more politically advantageous to be ambiguous about policy goals, to hide the true costs of implementing a policy, to promote second-best options, and to neutralize opposition by packaging policies with other legislation. With awareness of how good policy and good politics can work against each other, this paper is a plea to policymakers that before choosing any particular technology to support or mandate, that they first clarify the goal or target they want to achieve. Is the technology in question the most efficient way to meet the policy goal? Focusing on the desired goal or target will increase the chances that policies will be rational and efficient. There are a number of market failures in this area that do merit policies: improving knowledge about alternative fuels, reducing $\mathrm{CO} 2$ emissions, reducing dependence on oil imports and assisting farmers. But if we have these four goals we need at least four different instruments. 